\title{
ASTMUL ÎN FIBROZA CHISTICĂ
}

\author{
Asist. Univ. Dr. Marcela Daniela Ionescu, Prof. Dr. Mihaela Bălgrădean, \\ Prof. Dr. Ioana-Alina Anca \\ Universitatea de Medicină şi Farmacie ,, Carol Davila“, Bucureşti
}

\begin{abstract}
REZUMAT
Fibroza chistică (FC) este cea mai comună afecțiune autozomal recesivă la populația caucaziană. Boala pulmonară se caracterizează prin afectarea clearance-ului mucociliar cu obstrucția căilor aeriene, infecție şi inflamație cronică. Wheezingul este un simptom comun în FC, dar în unele cazuri este determinat de prezența concomitentă a astmului. Nu există un consens în cum definim astmul în fibroza chistică, dar diagnosticul se bazează în principal pe istoricul personal şi familial de atopie al pacientului.
\end{abstract}

Cuvinte cheie: fibroză chistică, wheezing, astm, atopie

FC este o boală multisistemică complexă cauzată de defectele într-o singură genă. Este cea mai comună afecțiune autozomal recesivă la populația caucaziană, asociată cu moarte prematură. Manifestările pulmonare sunt responsabile pentru cea mai mare morbiditate şi mortalitate. (1) Boala pulmonară din fibroza chistică debutează devreme în timpul vieții şi se caracterizează prin afectarea clearance-ului mucociliar, cu obstrucția căilor aeriene, infecție şi inflamație cronică. Infecția bacteriană cronică endobronşică a fost asociată cu un răspuns inflamator intens, neutrofilic care distruge căile aeriene, afectează mecanismele locale de apărare ale gazdei şi facilitează infecțiile viitoare. Acest ciclu vicios al inflamației şi infecției, cu distrugerea căilor aeriene, duce la apariția progresivă a bronşiectaziilor, retenție de aer, afectarea schimburilor gazoase şi în final determină insuficiență respiratorie. $(2,3)$

Wheezingul esta un simptom comun în FC şi în timp ce la cei mai mulți pacienți este determinat de boala pulmonară subiacentă, în unele cazuri wheezingul e determinat de prezența concomitentă a astmului. Este dificil să determinăm care pacienți au combinație cu astmul şi care au simptome asemănătoare astmului, determinate de inflamația plămânului din FC. $(3,4)$
Patogeneza obstrucției căilor aeriene şi a wheezingului din FC invocă câteva mecanisme care se suprapun: edemul mucoasei căilor aeriene secundare infecției şi inflamației cronice, obstrucția mecanică prin secreții vâscoase anormale, contracția musculaturii netede a căilor aeriene determinată de stimularea mediatorilor inflamației eliberați de organismul gazdei. (5)

Astmul este o afectiune comună, dar diagnosticul de astm poate fi dificil de efectuat mai ales la preşcolari. Consensul Grupului Internaţional de Astm Pediatric defineşte astmul ca episoade repetate de wheezing şi/sau tuse într-un context clinic în care astmul are cea mai mare probabilitate şi alte condiții rare au fost excluse. Această definiție este nefolositoare la pacienții cu FC. (6,7) Sunt folosite definiții variate, care au în comun reversibilitatea obstrucției căilor aeriene şi inflamația cronică a acestora. Simptomele clasice ale astmului sunt wheezing, tuse, dispnee şi presiune toracică. Pentru diagnosticul astmului sunt importante: istoricul, documentarea reversibilității obstrucției bronşice, alergia, testarea hiperreactivității bronşice, demonstrarea inflamației căilor aeriene când e posibil. (7)

Este destul de greu să defineşti astmul în FC, dar o încercare a fost efectuată într-un Studiu Epidemiologic efectuat în Canada şi Statele Unite 
(ESCF). Pacientul este raportat ca având astm concomitent dacă, în opinia medicului curant, astmul contribuie semnificativ la boala pulmonară a acestuia. Diagnosticul de astm este sugerat de următoarele: episoade de obstrucție acută de căi aeriene, reversibile la bronhodilatatoare (apărute mai ales sezonier); un istoric important de astm şi/sau evidente de atopie (eczema sau febra fânului); evidențe de laborator de alergie cum ar fi eozinofilia sau creşterea IgE. Această definiție este acceptată, deşi utilizarea IgE din ser şi a eozinofiliei are valoare dacă aspergiloza bronhopulmonară alergică (ABPA) a fost exclusă. $(4,6,7,8)$

\section{CUM PUTEM DIAGNOSTICA ASTMUL ÎN FIBROZA CHISTICĂ?}

Unele simptome au puțină relevanță pentru pacientul cu fibroza chistică. De exemplu, un istoric de wheezing este important, dar nespecific şi cei mai mulți pacienți cu FC au tuse recurentă chiar dacă au sau nu astm. Probabil cei mai importanți indicatori sunt: un istoric familial de atopie (inclusiv astmul) şi un istoric personal de eczemă şi rinită alergică. Examenul clinic nu este de ajutor, hiperinflația este comună atât în astm, cât şi în FC. $(3,5,6)$ Semnele clinice precoce includ creşterea diametrului anteroposterior al toracelui, hipersonoritate generalizată, raluri crepitante groase difuze sau localizate. Cianoza este un semn tardiv.

\section{FUNCȚIA PULMONARĂ}

Spirometria standard poate indica prezența obstrucției de căi aeriene. Nu diferențiază obstrucția determinată de un astm concomitent de cea determinată de boala pulmonară din FC. Măsurarea funcției căilor respiatorii mici, cum ar fi debitul expirator maxim la $25 \%$ din capacitatea vitală, nu este de ajutor deoarece tendința este la scădere la cei mai mulți pacienți şi aceasta este relativ variabilă.

Măsurarea debitului expirator maxim de vârf (PEF) este adesea folosit, cu excepția fibrozei chistice, unde obstrucția interesează în principal căile aeriene mici şi medii. Scăderea PEF este un semn tardiv. (2-6) Bodyplethismografia poate da informații suplimentare, inclusiv gradul de hiperinflație şi rezistența căilor aeriene, dar nu este specifică astmului din fibroza chistică. $(4,6)$

\section{HIPERREACTIVITATEA BRONŞICĂ}

Hiperreactivitatea bronşică (HRB) este comună la pacienții cu FC la orice vârstă. Testele de HRB nu se fac de rutină în pediatrie. HRB la histamină sau methocolină este întâlnită la cel puțin $40 \%$ dintre pacienții cu FC. $(4,9)$ Dacă HRB este măsurată în fibroza chistică utilizând teste de provocare, mulţi pacienți manifestă perioade de creştere a reactivităţii bronşice, în special în timpul şi imediat după, o exacerbare infecțioasă. $(1,6,9)$ Hiperresponsivitatea căilor aeriene în fibroza chistică diferă în răspunsul la bronhospasmul indus de histamină, care este reversibil la ipratropium la pacienții care nu au astm, în timp ce ipratropiumul nu este eficient în reversibilitatea bronhospasmului indus de histamină la pacienții cu simptome concomitente de astm. Acest lucru sugerează că HRB la pacienții cu fibroză chistică este mediată vagal şi este rezultatul afectării căilor aeriene datorate bolii pulmonare de bază. (10)

Răspunsul la stimuli indirecți cum ar fi soluția salină hipertonă sau exerciţiul fizic este diferit în fibroza chistică, deoarece pacienții prezintă de obicei bronhodilatație după astfel de provocări. (10)

Testarea la efort are un rol important în evaluarea ambelor afecțiuni. Diferențele între răspunsul la efort fizic în ambele condiţii sunt importante. În astm, după o perioadă tranzitorie normală de bronhodilatație, apare progresiv bronhoconstricția şi este maximă la 5-10 minute după oprirea efortului. Simptomele de obicei dispar între 15-30 de minute şi funcția pulmonară revine la normal între 30-60 de minute. În fibroza chistică este o creştere marcată a debitului expirator maxim de vârf (PEF) în timpul exercițiu-lui, care este cu atât mai exagerată la cei cu boală pulmonară mai gravă. După efortul fizic, scăderea PEF este mai puțin extinsă decât în astm. Probabil principala cauză a acestor rezultate este instabilitatea căilor aeriene din fibroza chistică. $(1,4,6,10,11)$

Toți pacienții cu FC ar trebui testaţi pentru a vedea dacă spirometria se îmbunătățeşte după utilizarea unui bronhodilatator (ex. salbutamol, terbutalina sau ipratropium bromide) în aerosol sau nebulizări (11).

Răspunsul la bronhodilatatorii este recomandat pentru diagnosticul astmului, dar utilitatea lui în diagnosticului astmului în FC, este puțin evidentă. Motivul pentru aceasta este datorat gradului de variabilitate în măsurarea funcției pulmonare (care poate varia cu până la $15-20 \%$ spontan, inclusiv testele din aceeaşi zi). Pacienții cu fibroză chistică arată adesea un grad de răspuns la bronhodilatatorii chiar dacă au sau nu astm, dar cele mai multe studii nu au găsit o relație cu atopia. $(4,6)$

Hiperreactivitatea căilor aeriene în FC este de mult timp recunoscută şi mulți pacienți cu FC au 
wheezing. Acesta poate fi determinat de bronhospasm, edem al mucoasei şi retenția de secreții în căile aeriene. Odată ce asprgiloza bronhopulmonară alergică şi refluxul gastroesofagian au fost excluse, putem folosi medicație pentru aceasta. $(4,6,11)$

Pacienții cu fibroză chistică şi astm concomitent, se manifestă cu simptome acute recurente de dispnee care răspunde impresionant la administrarea inhalatorie de $\beta 2$-agonişti şi/sau corticosteroizi sistemici (8). Totuşi mulți alții au un grad de reversibilitate la bronhodilatatori în absența unui răspuns clinic bun la tratamentul antiasmatic. În contrast cu cei cu astm, exercițiul nu induce bronhospasm şi poate chiar cauza bronhodilatație la pacienții cu fibroză chistică care au răspuns la bronhodilatator, în absența astmului. (4,6,8-10)

\section{ATOPIA}

IgEtotal în ser pot fi un ghid al statusului atopic al pacientului. Testele prick pozitive sau testele RAST din ser (radioallergosorbent tests) vor indica statusul atopic când alergeni comuni de tipul prafului de casă, câine, pisică, polenuri de ierburi şi arbori, sunt testați. O reacție la Aspergilus nu denotă întotdeauna atopie şi nu ar trebui să facă parte din screeningul atopic al fibrozei chistice. Prevalența atopiei în FC este în fapt, similară cu cea din populația non-fibroza chistică. (1-6) Este bine stabilit ca pacienții cu fibroză chistică atopici, au afectare pulmonară mult mai gravă.

\section{DIAGNOSTICUL DIFERENȚIAL}

La pacienții cu FC şi wheezing dificil de controlat, anumite condiții trebuie excluse şi trebuie să facă parte din diagnosticul diferențial al astmului din fibroza chistică. Acestea pot să coexiste.

Traheo-bronhomalacia trebuie exclusă prin bronhoscopie cu bronhoscop flexibil. Importanța acestui diagnostic este că poate mima simptome de astm, dar se pot înrăutăți datorită relaxării musculaturii netede de către bronhodilatatorii.

Refluxul gastroesofagian este comun la sugarii cu FC, dar problemele persistă la mulți copii mari şi adulți. Esta bine stabilit ca refluxul este asociat cu bronhospasmul și wheezingul. Necesită studiu $\mathrm{pH}-$ metric pe 24 de ore pentru a confirma diagnosticul. $(3,5)$

Aspergiloza bronhopulmonară alergică trebuie exclusă, deşi uneori diagnosticul este dificil. Cazurile clasice sunt simplu de diagnosticat. Totuşi multe simptome şi semne ale ABPA sunt comune şi mimează boala pulmonară din FC. Consensul Con- ferinței Fundației de Fibroză chistică propune criterii de diagnostic pentru ABPA, criterii minime de diagnostic şi recomandări de screening. $(12,13)$

Boala severă obstructivă a căilor respiratorii mici este dificil de definit cu precizie. Copiii au wheezing greu de tratat şi adesea spută cu expectorație minimă, deşi plămânii sunt plini de secreții. Tomografia pulmonară de înaltă rezoluție (HRCT) poate fi utilă pentru pacientul care nu răspunde la tratamentul standard. Se evidențiază boala extinsă a căilor aeriene mici, manifestată prin retenția distală de aer, determinată de bronşiolita obliterantă fixă. $(4,6,11,12)$.

\section{TRATAMENT}

Mulți pacienți cu exacerbare în fibroza chistică au, de asemenea, şi hiperrectivitate a căilor aeriene şi se observă o îmbunătățire a funcției pulmonare la pacienții spitalizați care primesc nebulizări regulate cu salbutamol. Agoniştii $\beta$-adrenergici cresc frecvența bătăilor ciliare şi pot afecta secreția de mucus $(11,14,15)$. Terbutalina s-a observat că stimulează secreția de ioni de clor în lumen şi pot creşte hidratarea căilor aeriene (10). Teofilina crește clearanceul mucociliar, contractilitatea diafragmatică, antrenează centrii respiratori din sistemul nervos central şi poate fi, de asemenea, antiinflamatorie, cel puțin în contextul astmului, la pacienții făă fibroză chistică. Unele studii arată că teofilina poate fi benefică în astmul din fibroza chistică. (10)

Corticosteroizii inflamatori (CSI) sunt în mare măsură prescrişi în fibroza chistică, adesea fără prea multe justificări. La sugari se prescriu adesea înainte de diagnostic, deaorece simptomele lor sunt atribuite astmului. Un alt motiv pentru care CSI sunt prescrişi pacienților cunoscuți cu fibroză chistică, este credința greşită că zgomotul descris de pacient sau familie este legat de bronhospasm şi nu de secrețiile din căile respiratorii. Cei mai mulți cred că administrarea de CSI pentru scăderea inflamației din FC, nu este o strategie corectă. Prin urmare singura indicație de utilizare a lor în fibroza chistică este dacă pacientul are astm. $(1,11,14)$

Abordarea unui tratament în trepte a fost propus pentru astm de către toate ghidurile internaționale. La pacienții cu astm necontrolat trebuie luată în considerare o treaptă superioară de tratament. (7) La pacienții cu fibroză chistică şi astm, tratamentul urmează progresia standard în trepte folosită în astmul bronşic: bronhodilatatori cu acțiune scurtă, corticosteroizi inhalatori, $\beta$ agonişti cu durată lungă de acțiune, teofilina (care poate îmbunătăți clearance-ul mucociliar), antagonişti de receptori de 
leukotriene (evidențe limitate în FC, pot scădea inflamația eozinofilică), steroizi orali. Răspunsul individual la tratamentul antiastmatic poate fi de ajutor în diagnosticul astmului asociat fibrozei chistice. $(4,6,10,14-16)$

\section{CONCLUZII}

$\mathrm{Nu}$ este un consens în definirea astmului din fibroza chistică. Suprapunerea între simptomele bolii pulmonare din fibroza chistică şi cele din astm şi faptul că ambele condiții sunt caracterizate de reactivitate bronşică, obstrucție variabilă a căilor respiratorii şi exacerbări infecțioase, complică precizia diagnosticării astmului în fibroza chistică.

Factorii care susțin diagnosticul de astm în fibroza chistică sunt: istoricul de wheezing recurent, istoricul familial pozitiv de atopie, istoricul de atopie al pacientului (eczemă, febra fânului, alergii alimentare), teste prick cutanate şi teste RAST din ser pozitive (cu excepția Aspergillus), valori crescute în ser ale IgE (cu excepția ABPA). Testarea funcției pulmonare (spirometrie, reversibilitate la bronhodilatator, hiperreactivitatea bronşică), excluderea altor diagnostice (refluxul gastroesofagian, traheobronhomalacia, ABPA, bronşiolita obliterantă) şi răspunsul la medicația antiastmatică, pot ajuta la diagnostic. $(4,6,7)$

$\mathrm{Cu}$ toate acestea, este încă dificil de determinat cine are FC şi astm şi cine are simptome asemănătoare astmului, de expir prelungit, wheezing şi raluri crepitante cauzate de inflamația pulmonară de bază. O analiză a bazelor de date din America de Nord şi Europa arată că etichetarea pacienților cu fibroză chistică şi astm concomitent influențează prescripția de medicamente $(4,6)$. Identificarea pacienților $\mathrm{cu}$ astm concomitent semnificativ este totuşi importantă, deoarece pot beneficia de medicaţia specifică astmului, în special corticosteroizi inhalatori. (11)

Indiferent dacă wheezingul este datorat unui astm concomitent sau nu, tratamentul urmează progresia standard folosită în astm. Oricare ar fi terapia prescrisă de medic, aceasta trebuie continuată, numai dacă beneficiile sunt dovedite în mod obiectiv. 